misclassification bias explaining our results produced by dictatorships worsening their health figures for international agencies seems remote.

The underlying mechanisms for the association between democracy and health are still unknown. Democracies allow for more space for social capital (for example, social networks, pressure groups), ${ }^{12}$ opportunities for empowerment, better access to information, and better recognition by government of people's needs. ${ }^{13}$ As we describe a new relation in the literature, our finding should be confirmed using longitudinal designs and potential causal pathways explored. If the relation is confirmed, the extent of freedom of a country could provide a new approach to decreasing national mortality.

The way societies organise themselves through their political regimes and their egalitarian policies could have a more important role in health than structural variables such as wealth and the size of the public sector. Increasing democratisation may be a way to counteract the deleterious effect on health of the unequal distribution of economic resources on a global scale. ${ }^{14}$

We thank Adrian Buzzaqui, Diana Gil, Tomás Pascual, Jaime Latour, and Miquel Porta for shaping the hypothesis, making it testable, and analysing the data.

Funding: The PhD programme of Public Health, University of Alicante, holds a grant from the Centro de Estudios Mario Benedetti. The Observatory of Public Policies and Health is a research consortium of the universities of Alicante, Antioquia, Porto-Alegre, and San Salvador, which holds grants from the Spanish Agency for International Cooperation and the Generalitat Valenciana.

Contributors: CA-D and MTR developed the hypothesis. All the authors analysed the data, interpreted the results, and drafted the manuscript. CA-D is guarantor.

Competing interests: None declared.

\section{Summary points}

Data now available make it possible to measure the global impact on health of a wide range of political and economic variables

Freedom ratings can be used as proxies to explore the effects of democracy on other variables

After a country's wealth, level of inequality, and the size of its public sector are adjusted for, democracy has a beneficial effect on health

1 Sen A. Poverty and famines: an essay on entitlement and deprivation. Oxford: Clarendon Press, 1982

Benaroyo L. Rudolf Virchow and the scientific approach to medicine. Endeavor 1998;22:114-7.

3 Porta M, Alvarez-Dardet C. Epidemiology: bridges over (and across) roaring levels. J Epidemiol Community Health 1998;52:605.

4 Kelleher CC. How exactly do politics play a part in determining health? Kelleher CC. How exactly do politics play a part in determining health?
New perspectives on an age old issue. J Epidemiol Community Health 2002;56:726

5 Navarro V, Borrell C, Benach J, Muntaner C, Quiroga A, Rodriguez-Sanz $\mathrm{M}$, et al. The importance of the political and the social in explaining mortality differentials among the countries of the OECD, 1950-1998. Int J Health Serv 2003;33:419-94.

6 Woodward D, Drager N, Beaglehole R, Lipson D. La globalización y la salud: marco de análisis y acción. Bull WHO 2002;32:32-8.

Freedom House. Freedom in the world country ratings 1972-73 to 20012002. www.freedomhouse.org (accessed 15 Nov 2003).

8 Lake D, Baum M. The invisible hand of democracy: political control and Lake D, Baum M. The invisible hand of democracy: political control
the provision of public services. Comp Polit Stud 2001;34:587-621.

Wilkinson RG. Income distribution and life expectancy. BMJ 1992;304: Wilkin 165 .

165-8.
0 Wilkinson RG. Socioeconomic determinants of health: health inequalities: relative or absolute material standards? BMJ 1997;314:591-5.

11 Freedom House. Freedom in the world 2003: survey methodology. www.freedomhouse.org/research/freeworld/2003/methodology.htm (accessed Nov 2004).

12 Baum FE, Ziersch AM. Social capital. J Epidemiol Community Health 2003;57:320-3.

13 Baum FE. Just imagine politicians working for health equity. J Epidemiol Community Health 2001;55:290.

14 Franco A. Globalizar la salud. Gac Sanit 2003;17:157-63.

\title{
Commentary: Politics as a determinant of health
}

\author{
Christopher Martyn
}

So, Franco et al found that people living in democracies enjoy better health than those who must endure repressive regimes. ${ }^{1}$ That's good to knowat least for those fortunate enough to live in freedom. But, in a perverse kind of way, I cannot help thinking that it would have been more interesting if things had been the other way around. Suppose it turned out that one had to pay a price, in terms of health, for the privilege of living in an electoral democracy. It would certainly have given us cause to reflect on the value we place on our rights and institutions.

As a thought experiment, imagine that you are a participant in one of those time trade-off investigations that health economists use to determine the utility of different states of health. Ask yourself how many years of life you would be prepared to sacrifice to gain a vote? Or how high a level of infant mortality you would tolerate in exchange for freedom of association and the right to say what you liked without fear that the secret police would come knocking?

\section{Strength of evidence}

Actually, I doubt that anyone would have believed it had the finding been the other way around. No matter how hard you try to guard against it, there is always a tendency to require a higher standard for evidence that challenges your prejudices than for evidence that supports them. If health had been positively associated with political repression, would the paper have survived peer review and the rigours of the selection process of the $B M$ ?

This sort of ecological survey is notoriously vulnerable to confounding. The investigators tried to take account of wealth, inequality, and the size of the public sector in their analysis, but surely peer reviewers would have queried whether the link between democracy and health was weaker in the multiple regression model by the inclusion of education, birth rate, the age structure of the population, and civil war? Provision of education seems especially likely to be a confounding variable since it is well established that women's education in particular has strong negative effects on both fertility and infant mortality, ${ }^{2}$ and that democracies spend more on education. ${ }^{3}$ 
I also suspect that reviewers and editors would have demanded a finer grained analysis if the results had been different. The investigators do not explain why they used the three categories of free, partially free, and not free to characterise the extent of democracy when Freedom House rates each country on a 7 point scale both for political rights and for civil liberties and makes these data available on its website. ${ }^{4}$ The quality of the data was also problematic. Although the information on life expectancy and maternal and infant mortality from the Human Development Report is no doubt the best available, the report acknowledges its many gaps and discrepancies. ${ }^{5}$

\section{Implications}

Let us put methodological issues aside and take the findings at face value. What can we usefully make of this cross sectional association between political freedom and health? After all, it is obvious that the way people live (and therefore how healthy they are) is shaped by political, social, demographic, economic, and cultural forces. Choices made by individuals about what they eat, where they work, what they do in their leisure time, the age at which they start their families, and how they look after their children are inevitably and heavily influenced by the society in which they live.

Our current preoccupation with risk factor epidemiology tends to obscure the fact that many of the forces that affect health and disease operate not at an individual level but on groups. The biological mechanisms by which these group level forces act are often obscure, but one example to the contrary is herd immunity. Although herd immunity is a powerful determinant of a person's risk of infectious disease, it is not a property that can be adequately captured by making measurements on individuals. The effects on health of large scale forces such as urbanisation, industrialisation, population growth, changes in the age structure of the population, racial discrimination, poverty, and inequality are likely to be profound. Franco et al would like us to add democratisation to this list and argue that there's a need for political epidemiology. If they mean that we should think about and investigate how the way a society organises and conducts itself affects the health of its members, who could disagree?

\section{Competing interests: None declared.}

Franco A, Alvarez-Dardet, Ruiz MT. Effect of democracy on health ecological study. BMJ 2004;329:1421-3.

Brown DS. Democracy and gender inequality in education: a cross national examination. Br J Polit Sci 2004;34:137-92.

3 Brown DS, Hunter W. Democracy and human capital formationeducation spending in Latin America, 1980 to 1997. Comp Polit Stud 2004;37:842-64.

4 Freedom House. www.freedomhouse.org/reseach/freeworld/2003/ metholodogy.htm [Author: Page not found. For urls you will need to provide a title and the date accessed please]

5 Human Development Report. Note on statistics. hdr.undp.org/statistics about/note_on_stats.cfm (accessed 10 Dec 2004)

\section{Lifestyle, health, and health promotion in Nazi Germany}

\section{George Davey Smith}

Several health related behaviours came under scrutiny in the 1930s and '40s in Germany, but did the associated campaigns achieve any benefits?

Department of Social Medicine,

University of

Bristol, Bristol BS8 2PR

George Davey Smith

professor

zetkin@bristol.ac.uk

BMJ 2004;329:1424-5
It may seem paradoxical that the robust identification of one of the most important environmental causes of disease of the 20th century occurred in a totalitarian state. The first case-control study of smoking and lung cancer originated in Nazi Germany in 1939 and found that heavy smoking was strongly related to the risk of lung cancer. Such research occurred against a backdrop of considerable official concern in Germany on the health damaging effects of smoking. Dr Leonard Conti, the Reich health führer, established the Bureau against the Dangers of Alcohol and Tobacco in 1939. ${ }^{1}$ In 1942 the Institute for the Struggle against the Dangers of Tobacco was established at the University of Jena, where a second case-control study of smoking and lung cancer was carried out. ${ }^{2}$ This was a convincing investigation in which the authors showed a sophisticated understanding of the potential biases that could distort epidemiological findings. The institute from which this study was run was supported by 100000 reichsmark of Adolf Hitler's personal finances. ${ }^{1}$

As well as research on smoking there was much antismoking health promotion in Nazi Germany. ${ }^{3}$ The Hitler Youth and the League of German Girls disseminated antismoking propaganda, and in 1939 Hermann Göring issued a decree forbidding the military from smoking on the streets and during marches or brief offduty periods. In 1942 the Federation of German Women launched a campaign against tobacco and alcohol misuse. Such campaigns were backed by legislation, and smoking was banned for both pupils and teachers in many schools. From July 1943, tobacco use was outlawed in public places for anyone aged less than 18 years. It was considered criminal negligence if

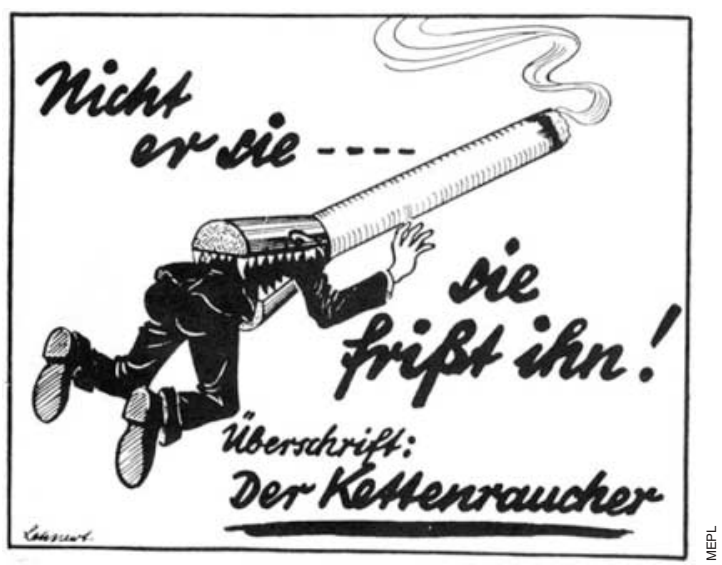

He doesn't eat her, she devours him. Signed by "the Chainsmoker" 